\title{
BRAF gene mutations in synchronous papillary thyroid carcinoma and Langerhans cell histiocytosis co-existing in the thyroid gland: a case report and literature review
}

\author{
Mohammad A. Al Hamad ${ }^{1,3^{*}}$ (D), Hassan M. Albisher², Weam R. Al Saeed ${ }^{1}$, Ahmed T. Almumtin²,
} Fatimah M. Allabbad ${ }^{2}$ and Mohammed A. Shawarby ${ }^{1}$

\begin{abstract}
Background: Langerhans cell histiocytosis $(\mathrm{LCH})$ is a rare clonal disease, characterized by hyperproliferation of Langerhans cells. It may rarely involve the thyroid gland. Its association with papillary thyroid carcinoma (PTC) is extremely rare; with only few case reports available in the English literature. BRAF mutations are implicated in the development of papillary thyroid carcinoma, and have also been identified in Langerhans cell histiocytosis.

Case presentation: Here we present a rare case of a 36-year-old Indonesian female patient with dysphagia associated with neck mass which was complicated by skin sinus formation. The diagnosis of PTC was rendered on fine needle aspiration (FNA). Debulking thyroidectomy revealed co-existeence of PTC and LCH. On subsequent molecular testing, BRAF V600E and V600K mutations were detected in tissues macrodissected from both lesions, respectively. To the best of our knowledge, this case is the first case to report two different BRAF mutations in tissues of a Langerhans cell histiocytosis and a papillary thyroid carcinoma co-existing in the thyroid gland. The patient received chemotherapy of etoposide combined with prednisone. At the most recent follow-up, the patient is in a stable clinical condition.

Conclusions: The coexistence of a PTC with LCH harboring BRAF mutation may suggest etiologic relation between the two conditions that involves the BRAF gene. Clinically, it may suggest an aggressive, locally advanced thyroid cancer, an impression that may reflect on the selected surgical management, chemotherapy and BRAF mutationtargeting therapy to these patients.
\end{abstract}

Keywords: BRAF gene mutations, Papillary thyroid carcinoma, Langerhans cell histiocytosis

\footnotetext{
* Correspondence: mhamad@iau.edu.sa

The diagnosis of this case has been conducted at King Fahd Hospital of University, Pathology, College of Medicine, Imam Abdulrahman Bin Faisal University, Saudi Arabia.

'Department of Pathology, College of Medicine, Imam Abdulrahman Bin Faisal University, Dammam, Saudi Arabia

${ }^{3}$ Department of Pathology and Laboratory Medicine, King Fahad Hospital of the University, PO Box 2208, Khobar 31952-2208, Saudi Arabia

Full list of author information is available at the end of the article
}

(c) The Author(s). 2019 Open Access This article is distributed under the terms of the Creative Commons Attribution 4.0 International License (http://creativecommons.org/licenses/by/4.0/), which permits unrestricted use, distribution, and reproduction in any medium, provided you give appropriate credit to the original author(s) and the source, provide a link to the Creative Commons license, and indicate if changes were made. The Creative Commons Public Domain Dedication waiver (http://creativecommons.org/publicdomain/zero/1.0/) applies to the data made available in this article, unless otherwise stated. 


\section{Background}

Thyroid cancer is the commonest malignancy of the endocrine system [1]. Most primary thyroid cancers originate from the epithelial cells that line the thyroid follicles. There are four main types of thyroid carcinoma, namely, papillary, follicular, medullary and anaplastic. Langerhans cell histiocytosis (eosinophilic granuloma) is a rare disease, characterized by a wide range of clinical presentations including isolated lesions, multiple lesions or multi organ disseminated disease. The disease is characterized by hyperproliferation of Langerhans cells that share similarities with antigen-presenting Langerhans cells of mucosal sites, thymus, lymph nodes and skin [2]. LCH does not arise from epidermal Langerhans cells, but from misguided myeloid dendritic cell precursors [3]. The debate over whether $\mathrm{LCH}$ is a neoplasm or a reactive inflammatory disorder has been discussed over many years. Evidence of clonality in LCH was reported in 1994 and, thereby, it is currently considered as a neoplastic process [2]. $\mathrm{LCH}$ may rarely involve the thyroid gland. Its association with PTC is also extremely rare, with only few case reports available in the literature [1-8]. Table 1 represents the cases of synchronous papillary thyroid carcinoma and Langerhans cell histiocytosis co-existing in the thyroid gland $[1,2,7-16]$. Herein, we report a case of co-existing PTC and $\mathrm{LCH}$ in the thyroid gland with detected BRAF V600E and V600K mutations respectively.

\section{Case presentation}

A 36-year-old woman was referred to the endocrine surgeon with a neck mass that gradually enlarged over a year. This mass was associated with dysphagia and complicated by skin sinus formation. There was no prior or family history of thyroid disease. Laboratory tests showed no evidence of thyroid hyper or hypo function.

Physical examination revealed a central neck skin sinus with a serosanguinous discharge (Fig. 1a). The thyroid gland was non-tender, diffusely enlarged, and extending bilaterally and retrosternally, mainly on the left side, with no cervical lymphadenopathy detected. Computerized tomography (CT) scan demonstrated a diffuse enlargement of the thyroid gland with skin infiltration, heterogeneous density and macrocalcification. The thyroid enlargement caused tracheal and esophageal compression and displaced neck vasculature laterally (Fig. 1b). Brain, chest, abdomen and pelvis $C$ Ts did not show any metastasis.

FNA from the right thyroid lobe was interpreted as PTC. The decision was to go for total thyroidectomy with

Table 1 Reported cases of synchronous co-existing of PTC and LCH in the thyroid gland

\begin{tabular}{|c|c|c|c|c|c|c|c|}
\hline Author/Year & Sex/Age & PTC\&LCH In Thyroid & Side & $\begin{array}{l}\mathrm{LCH} \text { in other } \\
\text { organs }\end{array}$ & Treatment & BRAF mutations & Follow up (months) \\
\hline $\begin{array}{l}\text { Goldstein } \\
\text { N, } 1991[9]\end{array}$ & $F / 31$ & Yes & Left & $\begin{array}{l}\text { Bone, Pituitary } \\
\text { gland, Lung, } \\
\text { Skin, Vagina }\end{array}$ & $\begin{array}{l}\text { Surgery, Prednisone, } \\
\text { Vincristine, Methotrexate, } \\
\text { Chlorambucil }\end{array}$ & NR & DF (6) \\
\hline Saiz E, 2000 [10] & $M / 43$ & Yes & Left & No & Surgery & NR & $\mathrm{DF}(24)$ \\
\hline $\begin{array}{l}\text { Foulet-Roge A, } \\
2002[11]\end{array}$ & $F / 42$ & Yes & Left & No & Surgery & NR & DF (14) \\
\hline Burnett A, 2008 [12] & $M / 3$ & $\begin{array}{l}\text { LCH in Right, } \\
\text { PTC in Left }\end{array}$ & Bilateral & Lung & $\begin{array}{l}\text { Surgery, Prednisone, } \\
\text { Mercaptopurine, } \\
\text { Methotrexate }\end{array}$ & NR & NR \\
\hline $\begin{array}{l}\text { Jamaati HR, } \\
2009[13]\end{array}$ & $M / 24$ & Yes & Bilateral & Lung & $\begin{array}{l}\text { Surgery, Etoposide, } \\
\text { Dexamethasone }\end{array}$ & NR & $\mathrm{DF}(\mathrm{NR})$ \\
\hline Vergez S, 2010 [1] & $M / 29$ & Yes & Bilateral & $\begin{array}{l}\text { Bone, } \\
\text { Pituitary gland, } \\
\text { Lung, Skin }\end{array}$ & $\begin{array}{l}\text { Corticosteroids, Vinblastine, } \\
\text { Cladribine, Imatinib }\end{array}$ & NR & $\operatorname{DRD}(36)$ \\
\hline Chung DH, 2012 [2] & $F / 53$ & Yes & Right & $N R$ & Surgery & NR & NR \\
\hline Ceyran AB, 2014 [14] & $M / 37$ & Yes & Bilateral & $N R$ & Surgery & NR & $\begin{array}{l}\text { Died due to } \\
\text { Cardiac arrest }\end{array}$ \\
\hline Gordon M S, 2016 [16] & $F / 22$ & Yes & Bilateral & Labia Vulva & Surgery, Prednisone & V600E in PTC & NR \\
\hline Alzahrani R, 2016 [7] & $F / 27$ & Yes & Bilateral & No & Surgery, CT Prednisone & NR & NR \\
\hline Wu X, 2017 [8] & $M / 40$ & Yes & Right & Lung, Liver & Surgery, CT & NR & $\mathrm{DF}(24)$ \\
\hline $\begin{array}{l}\text { Jaimanti Bakshi } \\
\text { JK,2018 [15] }\end{array}$ & M/31 & Yes & Right & No & $\begin{array}{l}\text { Surgery, Vinblastine } \\
\text { and Etoposide }\end{array}$ & NR & NR \\
\hline Current case & $F / 37$ & Yes & Bilateral & No & $\begin{array}{l}\text { Surgery, Prednisone } \\
\text { with Etoposide }\end{array}$ & $\begin{array}{l}\text { V600E in } \\
\text { PTC,V600K } \\
\text { in LCH }\end{array}$ & $\mathrm{DF}(12)$ \\
\hline
\end{tabular}




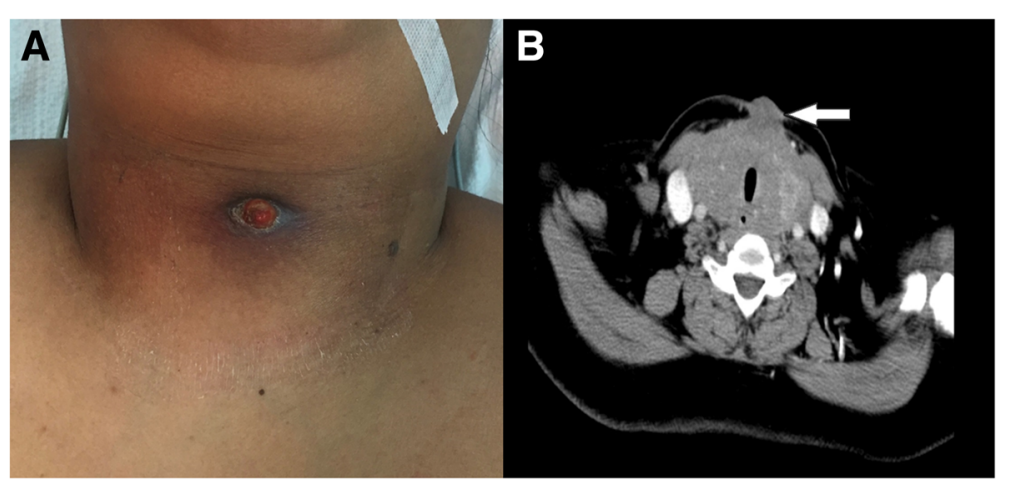

Fig. 1 Anterior midline neck sinus secondary to infiltrating thyroid cancer (a); CT scan transverse view: diffuse enlargement of thyroid gland infiltrating the skin with heterogeneous density (b)

central neck dissection. Intraoperatively, the thyroid gland was extremely adherent to the surrounding structures with infiltration of the skin, strap muscles and both carotid sheaths, and extensively adherent to the esophagus and trachea. Consequently, only debulking thyroidectomy (isthmectomy) was performed along with sinus track excision and sampling of the central lymph node compartment.

The thyroid specimen was received fragmented and consisted of multiple pieces of firm brown-tan tissue, measuring $5.5 \times 5 \times 0.4 \mathrm{~cm}$ in aggregate. Also received was an ellipse of skin and a "central" lymph node, measuring $5 \times 1 \times 0.7 \mathrm{~cm}$ and $1.5 \times 0.8 \times 4 \mathrm{~cm}$, respectively. Microscopic examination of sections from the thyroid gland revealed a classical PTC (Fig. 2a). In addition, there were cells with eosinophilic cytoplasm and mild to moderately pleomorphic nuclei, some showing irregular contours or grooves, admixed with inflammatory cells including numerous eosinophils. These cells were seen in extensive sheets replacing $60-70 \%$ of the resected thyroid tissue as well as focally within the neoplastic papillary cores (Fig. 2b). Similar cell sheets were seen in sections of the skin and lymph node. Immunohistochemically, the papillary carcinoma stained positively for pan cytokeratin (CK) (Fig. 2c) and cytokeratin 19 (CK19) (data not shown), while the infiltrating mononuclear cells showed diffuse, strong reactivity for CD1a (Fig. 2d), CD43, S100 protein and were negative for

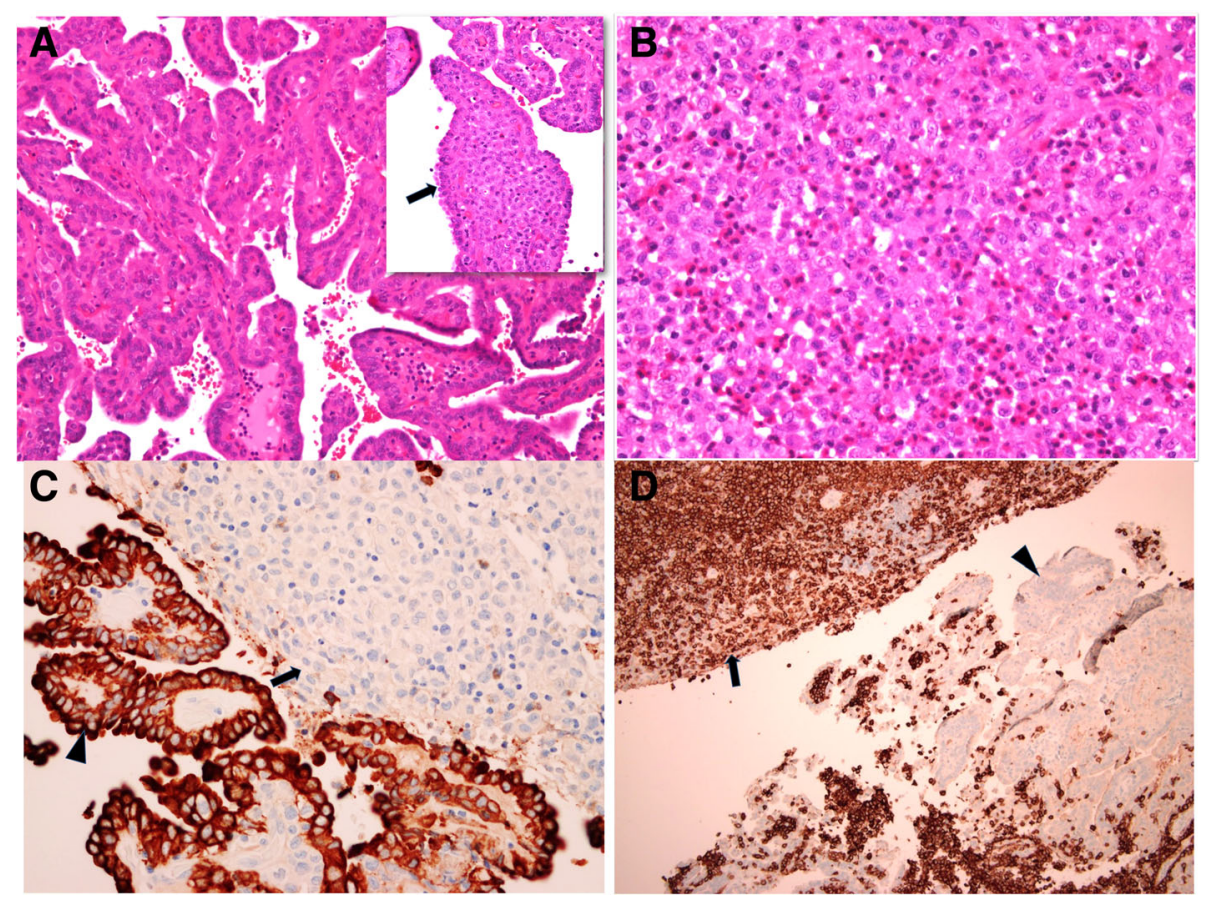

Fig. 2 Coexisting LCH and PTC. Focally extended to cores of PTC (inset, arrow), H\&E $\times 400$ (a); Sheets of LCH cells replacing thyroid parenchyma, H\&E $\times 200$ (b); PTC cells staining positively for panCK (arrow head); LCH cells are not stained (arrow), IHC $\times 400$ (c); LCH cells staining positively for CD1a (arrow); PTC cells are not stained (arrow head), IHC $\times 100(\mathbf{d})$ 
myeloperoxidase, LCA and HMB45 immunostians (data not shown). The Ki67 proliferation index in these cells was around 60\% (data not shown). The final diagnosis was synchronous PTC and LCH involving thyroid, overlying skin and cervical lymph node.

Paraffin blocks including both the PTC and the $\mathrm{LCH}$ were manually macrodissected. DNA was automatically extracted and purified by QIAcube (Qiagen) from the two lesions separately using QIAamp DNA FFPE, while the concentration and purity of extracted DNA was assessed by Epoch-Bioteck. BRAF mutations were investigating using Easy BRAF kit (Diatech) that detects BRAF codon 600 mutations by real-time PCR (Rotor-Gene). DNA was assessed by analysis of the reaction controls (water, BRAF positive control) and analysis of BRAF control mix. The two DNA samples extracted from the two different lesions passed the assessment of DNA, and then were analyzed to search for mutations. Mutational analysis of BRAF for the DNA extracted from PTC and LHC revealed V600E and V600K mutations, respectively (Fig. 3).

The postoperative course was uneventful. The patient received palliative chemotherapy, at her home country, that consisted of Etoposide with Prednisone. After twelve months of follow-up, the patient is in a stable clinical condition.

\section{Discussion and conclusions}

LCH has a broad spectrum of clinical presentations and may rarely involve the thyroid gland. There is probably some association between LCH and PTC, as few cases of $\mathrm{LCH}$ co-existing with PTC have been previously described in the English literature (Table 1).

Activating $B R A F$ mutations is an important event in the development of PTC $[17,18]$. BRAF V600E mutation has been reported in about $40-60 \%$ of patients with PTC [19]. A somatic activating BRAF V600E mutation has also been identified in approximately $60 \%$ of $\mathrm{LCH}$, strongly supporting the neoplastic rather than inflammatory nature of LCH [20]. However, no sufficient information is available in the literature, regarding the $B R A F$ mutation status of cases of co-existing $\mathrm{LCH}$ and PTC [1]. It has been speculated that the BRAF V600E mutation in LCH could lead to PTC through creating a microenvironment that is appropriate for neoplastic transformation [4]. To the best of our knowledge, our case is the first report of $B R A F$ mutations in tissues of a $\mathrm{LCH}$ and a PTC co-existing in the thyroid gland, suggesting an aggressive disease and etiologic relation between the two conditions that involves the BRAF gene. Since the patient decided to start the treatment at home country, there was limitation in the patient follow-up. Our case is the second case reported to harbor $B R A F$

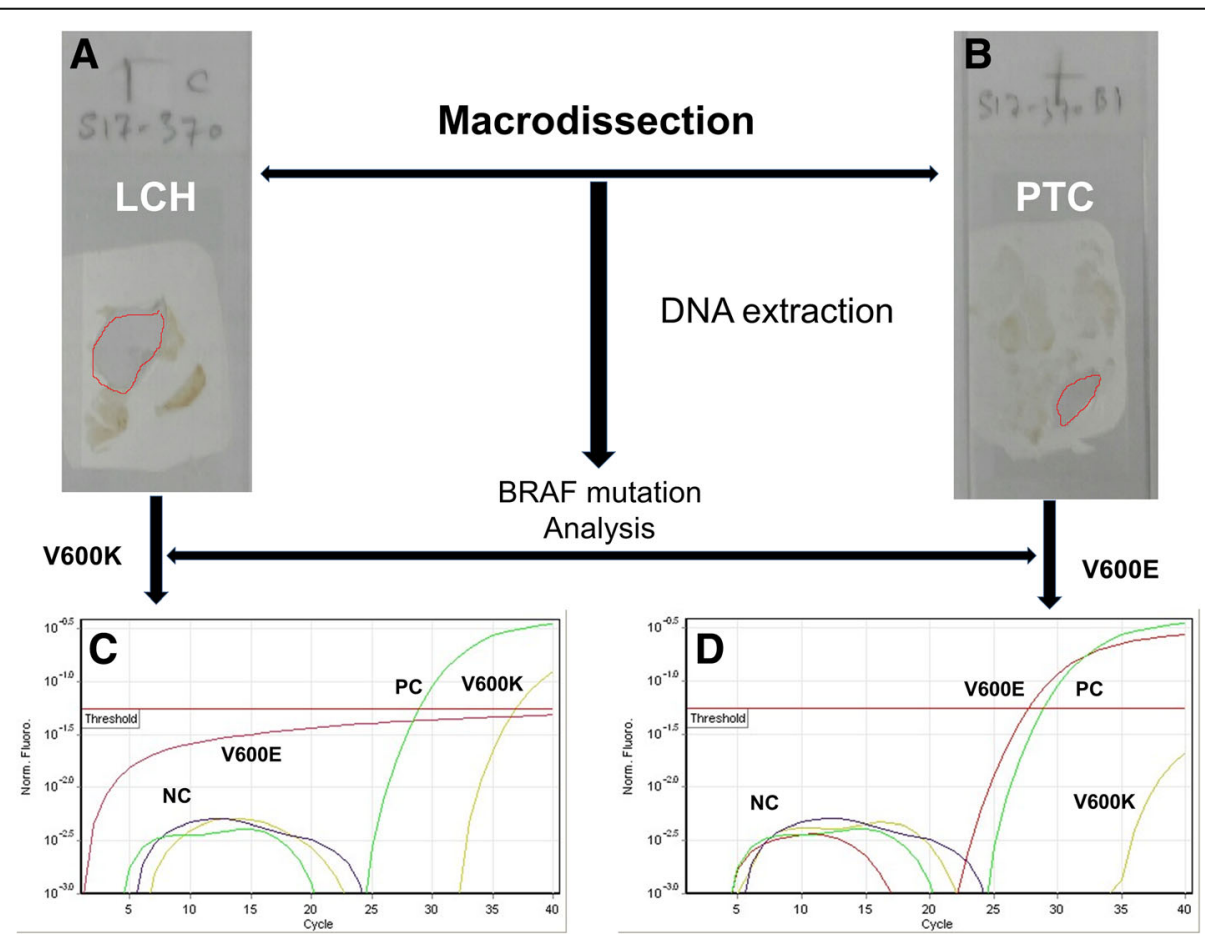

Fig. 3 BRAF gene mutations of LCH and PTC co-existing in the thyroid gland. Macrodissected LCH cells (marked red) from the thyroid gland (a); macrodissected PTC cells (marked red) from the thyroid gland (b); V600k BRAF mutation detected in the DNA extracted from LCH cells (c); V600E BRAF mutation detected in the DNA extracted from PTC cells (d); PC: positive control; NC: negative control 
V600K mutation in LCH [21]. The PTC was not iatrogenically induced as the patient did not receive any prior radiotherapy [22], while $\mathrm{LCH}$ patients showed improvement after chemotherapy [8].

The co-existence of $\mathrm{LCH}$ with an otherwise classical PTC may lead to a clinical impression of an aggressive, locally advanced type of thyroid cancer. This may affect the selection of surgical management. This was our experience in the present case in which only debulking thyroidectomy was attempted to relieve the compressive symptoms, as total thyroidectomy was not possible due to widespread local extension and the involvement of vital surrounding structures.

The clinical behavior of LCH is extremely variable. Some cases are limited in extent and follow an indolent course, whereas others exhibit multi organ involvement, frequent recurrences, and are refractory to conventional therapy. The presence BRAF V600E mutation was shown to be associated with high-risk features and poor response to chemotherapy in children with LCH [23]. Clinically and histologically, our case exhibited features suggestive of an aggressive behavior, namely, an extensively infiltrative pattern, lymph node involvement and a high Ki67 proliferation index.

In conclusion, co-existing PTC and $\mathrm{LCH}$ in the thyroid gland is extremely rare. The demonstration of $B R A F$ mutations in tissues obtained from both lesions suggests an etiologic relation between the two conditions and opens the door for further studies to investigate a possible etiologic connection between LCH and PTC.

The co-existence of BRAF mutated-LCH with an otherwise classical PTC may lead to a clinical impression of an aggressive, locally advanced type of thyroid cancer. This may have an impact on the surgical procedure selection, as well as post-surgical treatment.

\section{Abbreviations}

CT: Computerized tomography; FNA: Fine needle aspiration; LCH: Langerhans cell histiocytosis; PTC: Papillary thyroid carcinoma

\section{Acknowledgments}

The authors acknowledge the services of Mariam Alajmi MSc (Lab. Specialist), King Fahad Hospital of the University for the help in molecular tests.

\section{Funding}

We declare that no fund was received for this work.

\section{Availability of data and materials}

Al the data supporting the findings are present in the manuscript.

\section{Authors' contributions}

MA interpreted the results of molecular tests and contributed in drafting the article. HA performed the Clinical and operative workup of patient. WA contributed in interpretation of histological results. AA participates in follow up the patient. FA was responsible for acquisition of clinical, laboratory and radiological data. MS participated in Interpretation of the immunohistochemical results, and drafting the article. All authors read and approved the final manuscript.

\section{Ethics approval and consent to participate}

This research was approved by the research ethics committee of Imam Abdulrahman Bin Faisal and Informed consent as documented by signature was obtained from this patient.

\section{Consent for publication}

Written informed consent was obtained from the patient for publication of the Case Report and any accompanying images.

\section{Competing interests}

The authors declare that they have no competing interests.

\section{Publisher's Note}

Springer Nature remains neutral with regard to jurisdictional claims in published maps and institutional affiliations.

\section{Author details}

${ }^{1}$ Department of Pathology, College of Medicine, Imam Abdulrahman Bin Faisal University, Dammam, Saudi Arabia. ${ }^{2}$ Department of Surgery, College of Medicine, Imam Abdulrahman Bin Faisal University, Dammam, Saudi Arabia. ${ }^{3}$ Department of Pathology and Laboratory Medicine, King Fahad Hospital of the University, PO Box 2208, Khobar 31952-2208, Saudi Arabia.

Received: 13 September 2018 Accepted: 17 February 2019

Published online: 22 February 2019

\section{References}

1. Vergez S, Rouquette I, Ancey M, Serrano E, Caron P. Langerhans cell histiocytosis of the thyroid is a rare entity, but an association with a papillary thyroid carcinoma is often described. Endocr Pathol. 2010;21(4):274-6.

2. Chung DH, Ha SY, Cho HY, et al. Langerhans cell Histiocytosis in the thyroid and draining lymph nodes: a case report. Endocrinol Metab. 2012;27(2):4.

3. Safali M, McCutcheon JM, Wright DH. Langerhans cell histiocytosis of lymph nodes: draining a papillary carcinoma of the thyroid. Histopathology. 1997; 30(6):599-603

4. Moschovi M, Adamaki M, Vlahopoulos S, Rodriguez-Galindo C. Synchronous and metachronous thyroid cancer in relation to Langerhans cell histiocytosis; involvement of V600E BRAF-mutation? Pediatr Blood Cancer. 2015;62(1):173-4.

5. Lindley R, Hoile R, Schofield J, Ashton-Key M. Langerhans cell histiocytosis associated with papillary carcinoma of the thyroid. Histopathology. 1998; 32(2):180

6. Schofield JB, Alsanjari NA, Davis J, MacLennan KA. Eosinophilic granuloma of lymph nodes associated with metastatic papillary carcinoma of the thyroid. Histopathology. 1992;20(2):181-3.

7. AlZahrani R, Algarni M, Alhakami H, AlSubayea H, Alfattani N, Guler M, et al. Thyroid Langerhans cell histiocytosis and papillary thyroid carcinoma. Gland Surg. 2016;5(5):537-40

8. Wu X, Chen S, Zhang LY, Luo YP, Jiang Y, Feng RE. Langerhans cell histiocytosis of the thyroid complicated by papillary thyroid carcinoma: a case report and brief literature review. Medicine. 2017:96(35):e7954

9. Goldstein N, Layfield LJ. Thyromegaly secondary to simultaneous papillary carcinoma and histiocytosis $X$. Report of a case and review of the literature. Acta Cytol. 1991:35(4):422-6.

10. Saiz E, Bakotic BW. Isolated Langerhans cell histiocytosis of the thyroid: a report of two cases with nuclear imaging-pathologic correlation. Ann Diagn Pathol. 2000;4(1):23-8

11. Foulet-Roge A, Josselin N, Guyetant S, Gardet JJ, Besancon A, Saint-Andre $J P$, et al. Incidental langerhans cell histiocytosis of thyroid: case report and review of the literature. Endocr Pathol. 2002;13(3):227-33.

12. Burnett A, Carney D, Mukhopadhyay S, Scalzetti EM, Leino D, Souid AK. Thyroid involvement with Langerhans cell histiocytosis in a 3-year-old male. Pediatr Blood Cancer. 2008:50(3):726-7.

13. Jamaati HR, Shadmehr MB, Saidi B, Khosravi A, Arab M, Mohammadi F. Langerhans cell histiocytosis of the lung and thyroid, co-existing with papillary thyroid cancer. Endocr Pathol. 2009;20(2):133-6.

14. Ceyran AB, Senol S, Bayraktar B, Ozkanli S, Cinel ZL, Aydin A. Langerhans cell histiocytosis of the thyroid with multiple cervical lymph node involvement accompanying metastatic thyroid papillary carcinoma. Case Rep Pathol. 2014;2014:184237. 
15. Jaimanti Bakshi JK. Langerhans cell Histiocytosis co-existing with papillary carcinoma of thyroid - a rare surgical challenge. ARC J Cancer Sci. 2018;4(1):4.

16. Gordon MS, Gordon MB. Occult Langerhans cell Histiocytosis presenting with papillary thyroid carcinoma, a thickened pituitary stalk and diabetes insipidus. Case Rep Endocrinol. 2016;2016:5191903.

17. Cohen $Y$, Xing M, Mambo E, Guo Z, Wu G, Trink B, et al. BRAF mutation in papillary thyroid carcinoma. J Natl Cancer Inst. 2003;95(8):625-7.

18. Xing M, Alzahrani AS, Carson KA, Viola D, Elisei R, Bendlova B, et al. Association between BRAF V600E mutation and mortality in patients with papillary thyroid cancer. Jama. 2013;309(14):1493-501.

19. Ascierto PA, Kirkwood JM, Grob JJ, Simeone E, Grimaldi AM, Maio M, et al. The role of BRAF V600 mutation in melanoma. J TransI Med. 2012;10:85.

20. Badalian-Very G, Vergilio JA, Degar BA, MacConaill LE, Brandner B, Calicchio $\mathrm{ML}$, et al. Recurrent BRAF mutations in Langerhans cell histiocytosis. Blood. 2010;116(11):1919-23.

21. Sahm F, Capper D, Preusser M, Meyer J, Stenzinger A, Lasitschka F, et al. BRAFV600E mutant protein is expressed in cells of variable maturation in Langerhans cell histiocytosis. Blood. 2012;120(12):e28-34.

22. Jereczek-Fossa BA, Alterio D, Jassem J, Gibelli B, Tradati N, Orecchia R. Radiotherapy-induced thyroid disorders. Cancer Treat Rev. 2004:30(4):369-84.

23. Heritier S, Emile JF, Barkaoui MA, Thomas C, Fraitag S, Boudjemaa S, et al. BRAF mutation correlates with high-risk Langerhans cell Histiocytosis and increased resistance to first-line therapy. J Clin Oncol. 2016;34(25):3023-30.

Ready to submit your research? Choose BMC and benefit from:

- fast, convenient online submission

- thorough peer review by experienced researchers in your field

- rapid publication on acceptance

- support for research data, including large and complex data types

- gold Open Access which fosters wider collaboration and increased citations

- maximum visibility for your research: over $100 \mathrm{M}$ website views per year

At BMC, research is always in progress.

Learn more biomedcentral.com/submissions 